\title{
Demonstration of treponeme-like forms In cases of treated and untreated late syphilis and of treated early syphilis
}

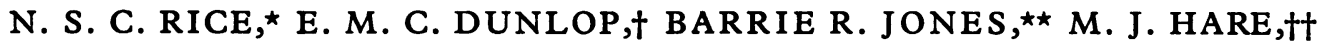

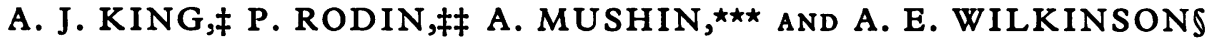 \\ * Senior Lecturer, Institute of Ophthalmology and Moorfields Eye Hospital \\ $\star \star \quad$ Professor of Clinical Ophthalmology, Institute of Ophthalmology and Moorfields Eye Hospital \\ $\star \star \star$ Senior Registrar, Moorfields Eye Hospital \\ † Senior Physician, Whitechapel Clinic, The London Hospital; Diagnostic Clinic, Moorfields Eye Hospital; \\ Institute of Ophthalmology \\ t† Research Registrar, Whitechapel Clinic, The London Hospital; Diagnostic Clinic, Moorfields Eye Hospital; \\ Institute of Ophthalmology \\ $\ddagger \quad$ Acting Physician, Diagnostic Clinic, Moorfields Eye Hospital \\ ¥ Physician, Whitechapel Clinic, The London Hospital \\ I Director, Venereal Diseases Reference Laboratory (PHLS), The London Hospital
}

Collart, Borel, and Durel (1962a, b, c, 1964), in France, showed by means of silver stains that treponemes that were apparently $T$. pallidum could be found in the lymph nodes and cerebrospinal fluid (CSF) of patients after treatment of late syphilis. One of these patients was a tabetic who had received over 150 million units of penicillin. These workers infected rabbits experimentally by transferring lymph node material from three patients. They also found treponemes in the lymph nodes of rabbits treated 2 years after experimental infection with syphilis. In both human and animal cases immobilizing antibody was still present. Results of further inoculations of rabbits suggested that the 'persistent treponemes' had partially or completely lost their virulence. It may well be relevant to the infection in man that active syphilitic lesions were precipitated in some treated rabbits by the administration of cortisone.

After using darkfield microscopy, fluorescent antibody techniques, and, in a few cases, after transfer of material to experimental animals or silver staining, workers in the United States of America, Italy, and Great Britain, have recently reported the presence of treponemes in material from patients suffering from late syphilis; these patients included some with negative results to serological tests for syphilis but definite signs of that disease, and others in whom the signs suggested the presence of tre-

Received for publication December 11, 1969

Applications for reprints to Dr. E. M. C. Dunlop ponemal infection but were not diagnostic (Yobs, Rockwell, and Clark, 1964; Boncinelli, Vaccari, Pincelli, and Lancellotti, 1966; Smith and Israel, 1967a, b, 1968; Smith, Israel, and Harner, 1967; Goldman and Girard, 1967, 1968; Christman, Hamilton, Heaton, and Hoffmeyer, 1968; Dunlop, King, and Wilkinson, 1968; Gager, Israel, and Smith, 1968; Rice, Jones, and Wilkinson, 1968; Smith, Israel, McCrary, and Harner, 1968; Wilkinson, 1968; Yobs, Clark, Mothershed, Bullard, and Artley, 1968; Mack, Smith, Walter, Montenegro, and Nicol, 1969; Montenegro, Israel, Nicol, and Smith, 1969). Treponemes that did not stain by means of an indirect immunofluorescence method were detected in aqueous humour from one of 47 control patients in whose case serological tests for syphilis had given negative results (Golden, Watzke, Lindell, and McKee, 1968); in the aqueous humour in congenital syphilis; and, together with treponemes showing typical fluorescence, in aqueous humour from a patient suffering from late syphilis (Goldman and Girard, 1968). The presence of treponemes that did not stain by means of a direct immunofluorescent technique, together with others showing typical fluorescence, has been reported in specimens from patients suffering from undoubted treponemal infection (Wilkinson, 1968).

Lesions in which the presence of treponemes has been reported have been produced in animals by the experimental inoculation of material from patients previously treated for syphilis in whose cases the 
treponemal immobilization test (TPI) had given persistently positive results (Collart and others, 1962a, b, c, 1964; Yobs and others, 1964, 1968), and also from a patient in whose case the fluorescent treponemal antibody-absorption test (FTA-ABS) gave a positive result (Smith and others, 1968). The step of establishing treponemal infection experimentally in animals by the use of material from a patient suffering from late syphilis but with negative results to serological tests, including the TPI and FTA-ABS, was taken by Smith and Israel (1968): they inoculated aqueous humour from a tabetic into one squirrel monkey and CSF into another; lesions in which the presence of treponemes was reported developed in both animals.

Wilkinson (1968) stated that forms resembling treponemes might be artefacts such as glass spirals or filaments. Montenegro, Nicol, and Smith (1969) reviewed the work of their group and reported that some of the findings, previously reported as treponemes, were artefacts although others were apparently treponemes.

Because of the limitations of morphological methods of diagnosis, forms that were considered to be morphologically typical of $T$. pallidum are reported as 'treponeme-like forms' in the present study.

\section{Patients studied}

This paper reports the results of darkfield microscopy and of fluorescent antibody techniques for the demonstration of treponemes in CSF, aqueous humour, and subretinal fluid obtained from a total of 42 patients, forty of whom were found to have definite evidence of treponemal infection. Of these patients, 21 attended the Whitechapel Clinic of The London Hospital where definite treponemal infection was diagnosed in all cases on grounds other than persistence of treponemes. In eighteen a diagnosis of acquired infection had been made (eight cases of neurosyphilis, two of treated primary syphilis, eight of late latent treponemal disease); in three cases long-standing congenital syphilis had been diagnosed. A further 21 patients attended Moorfields Eye Hospital because of ocular disease; of these, nineteen had definite evidence of treponemal infection: thus ten had either interstitial keratitis or the typical scarring that results from that disease, eight had anterior or posterior uveitis and positive results to serological tests for syphilis, and one presented because of a retinal tear and was also found to be sero-positive. The other two patients had choroidoretinal changes suggestive of syphilitic infection; repeated serological tests for syphilis in one case gave uniformly negative results and in the other case there was a history of treatment for syphilis but the TPI and FTA-ABS gave negative or 'doubtful' results. Only in these two cases did the diagnosis rest partly on the finding of treponeme-like forms.
In addition, in order to provide 'control' cases, aqueous humour from four patients suffering from diseases other than syphilis was examined, no treponeme was found (Rice and others, 1968; Dunlop and others, 1968).

\section{Methods}

Detailed histories were taken from all patients; all were examined clinically for evidence of treponemal infection and the following tests for syphilis were carried out on both serum and CSF: Venereal Disease Research Laboratory slide test (VDRL), cardiolipin Wassermann reaction (CWR), Reiter protein complement-fixation test (RPCFT) and FTA-ABS. The TPI was performed on sera but on only a minority of specimens of CSF.

Routine studies (cell count, protein estimation, Pandy $\subseteq$ test, Lange curve) were also carried out on the CSF. Results accepted as normal were: cell count less than six white blood cells (WBC)/c.mm., protein $40 \mathrm{mg}$./ $100 \mathrm{ml}$. or less, and negative Pandy and Lange tests.

The clinical procedure used for obtaining aqueous humour has already been described (Jones, Patterson, and Rice, 1968). Subretinal fluid was obtained during operation for retinal detachment. The methods used initially for the preparation and examination of specimens for treponemes have been reported (Wilkinson, 1968). CSF, aqueous humour, and subretinal fluid were examined by immunofluorescence microscopy. In addition CSF and subretinal fluid were examined, within 30 minutes of obtaining specimens, by means of darkfield microscopy using visible light.

Fluorescent-antibody (FA) staining In the earlier part of the study, slides were stained for $30 \mathrm{~min}$. at $37^{\circ} \mathrm{C}$. with the globulin fraction of high-titred human or rabbit syphilitic sera conjugated with fluorescein isothiocyanate and absorbed with Reiter treponemes to remove group $\stackrel{0}{=}$ antitreponemal antibody from the conjugate. Because of the possibility that antibody, derived from the patient and already on the treponemal surface, might inhibit $\delta$ union with the conjugate, this direct method was later replaced by an indirect one. Slides were first treated for $\mathrm{O}$ $30 \mathrm{~min}$. with human serum, that gave maximal $(++++) \stackrel{2}{2}$ fluorescence in the FTA-ABS, diluted 1 in 5 in the $\frac{7}{0}$ supernatant from ultrasonically disintegrated Reiter treponemes. Trials showed that the serum so treated $N$ retained reactivity with $T$. pallidum but not with the $G$ Reiter treponeme. After the slides had been washed in $\mathcal{O}$ buffered saline, an antihuman gamma globulin conjugate $\underset{\mathrm{N}}{\mathrm{N}}$ was applied for $30 \mathrm{~min}$. at $37^{\circ} \mathrm{C}$., and the slides were then washed and mounted in buffered glycerine.

Slides were examined by darkfield microscopy at a $\stackrel{0}{\subset}$ magnification of $\times 500$ with an HBO 200 light source, $\stackrel{\oplus}{\oplus}$ $3 \mathrm{~mm}$. BG12 primary filter, and appropriate barrier filters. The whole of the area within the inscribed circle $\frac{7}{3}$ was scanned systematically. Usually treponeme-like $\stackrel{0}{\Phi}$

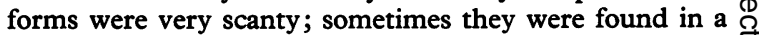
single field on only one of the four slides, so that a pro- $\mathbb{\Phi}$ longed and careful search was needed to detect them. Typically, the spiral shape of the organisms was well preserved and they fluoresced brightly. Treponemal 8 forms were classed as of 'doubtful' significance if, when using visible or ultraviolet light, the structure was not 
typical, the spirals being open rather than forming the tight-wound helix characteristic of $T$. pallidum; or if, when using ultraviolet light, the intensity of fluorescence was feeble. Each batch of slides included a control preparation of the Nichols strain of $T$. pallidum.

\section{Results}

Results of tests in the first nine cases and in the four control cases have been published (Rice and others, 1968; Dunlop and others, 1968); those cases already reported are here denoted, as before, by coded initials.

Specimens of CSF from 21 patients who attended the Whitechapel Clinic were tested; treponeme-like forms were found in six cases (Table I). Aqueous humour from eighteen patients who attended Moorfields Eye Hospital was tested; treponeme-like forms were found in ten cases and a 'doubtful' form in another. CSF specimens from sixteen of these eighteen patients and from two others presenting at Moorfields were examined; treponeme-like forms were found in three cases and a 'doubtful' form in another.

Subretinal fluid from two patients suffering from retinal detachment was tested; a 'doubtful' form was found in one case on darkfield microscopy.

Thus, treponeme-like forms were found in CSF from nine of 39 patients. The results of examination of the CSF by darkfield microscopy and by immunofluorescence microscopy are compared in Table II.

TABLE II Comparison of results of initial examination of CSF by darkfield and immunofluorescence

microscopy

\begin{tabular}{|c|c|c|c|c|c|}
\hline \multirow{2}{*}{$\begin{array}{l}\text { Immuno- } \\
\text { fluorescence } \\
\text { microscopy }\end{array}$} & \multicolumn{4}{|c|}{ Darkfield microscopy } & \multirow{2}{*}{ Total } \\
\hline & Positive & 'Doubtful' & Negative & Not done & \\
\hline Positive & 3 & 0 & 2 & 0 & 5 \\
\hline 'Doubtful' & 1 & 0 & 0 & 0 & 1 \\
\hline Negative & 3 & 1 & $26^{\star}$ & 3 & 33 \\
\hline Total & 7 & 1 & $28^{\star}$ & 3 & 39 \\
\hline
\end{tabular}

$\star$ In addition, Case 4 (Mr IT): subsequent test showed treponeme-like forms that stained by the FA method.
Darkfield microscopy gave positive results in three, and negative results in two of five specimens positive by immunofluorescence microscopy. Immunofluorescence microscopy gave positive results in three, a 'doubtful' result in one, and negative results in three of seven specimens positive by darkfield microscopy. Tests on CSF from one patient (Mr. IT, Case 4) were reported as negative by both methods, but after this study was completed a further test showed the presence of treponeme-like forms by FA staining.

Both aqueous humour and CSF were obtained from sixteen patients (Table III); treponeme-like forms were found in aqueous humour from ten and in CSF from three. In one case (Case 4, Mr. IT), however, the results of subsequent tests were reported as positive for CSF, and negative for aqueous humour. In Case 19, in which the result of the test of aqueous was reported as 'doubtful', that of CSF was reported as positive.

TABLE II I Comparison of results of initial examination of aqueous humour and CSF from 16 patients

\begin{tabular}{|c|c|c|c|c|}
\hline \multirow{2}{*}{$\begin{array}{l}\text { Aqueous } \\
\text { humour }\end{array}$} & \multicolumn{3}{|l|}{$C S F$} & \multirow{2}{*}{ Total } \\
\hline & Positive & 'Doubtful' & Negative & \\
\hline $\begin{array}{l}\text { Positive } \\
\text { 'Doubtful' } \\
\text { Negative }\end{array}$ & $\begin{array}{l}2 \\
1 \\
0\end{array}$ & $\begin{array}{l}0 \\
0 \\
1\end{array}$ & $\begin{array}{l}8^{\star} \\
0 \\
4\end{array}$ & $\begin{array}{c}10^{\star} \\
1 \\
5\end{array}$ \\
\hline Total & 3 & 1 & 12 & 16 \\
\hline
\end{tabular}

^Case 4 (Mr IT): subsequent tests reported as CSF positive, aqueous humour negative.

\section{Active inflammatory disease}

Active inflammatory disease of the eye was present in eleven patients from whom aqueous humour was obtained. Treponeme-like forms were found in aqueous humour in nine cases, but in another (Case 19) typical treponeme-like forms were found in CSF, although 'doubtful' forms were present in aqueous humour. In seven cases in which aqueous humour was obtained there was no clinical

TABLE I Results of initial tests for treponemes in 42 patients

\begin{tabular}{|c|c|c|c|c|c|c|c|c|c|c|}
\hline \multirow{2}{*}{ Presentation } & \multirow{2}{*}{$\begin{array}{l}\text { No. of } \\
\text { patients }\end{array}$} & \multicolumn{3}{|l|}{$C S F$} & \multicolumn{3}{|c|}{ Aqueous humour } & \multicolumn{3}{|c|}{ Subretinal fluid } \\
\hline & & Tested & Positive & 'Doubtful' & Tested & Positive & 'Doubtful' & Tested & Positive & 'Doubtful' \\
\hline \multicolumn{11}{|l|}{ At Whitechapel } \\
\hline Clinic & 21 & 21 & 6 & 0 & 一 & - & 一 & 一 & - & - \\
\hline At Moorfields & 21 & 18 & $3 \star$ & 1 & 18 & $10 \dagger$ & 1 & 2 & 0 & 1 \\
\hline Total & 42 & 39 & $9 \star$ & 1 & 18 & $10 t$ & 1 & 2 & 0 & 1 \\
\hline
\end{tabular}

^In addition, Case 4 (Mr IT): subsequent test showed treponeme-like forms that stained by the FA method; initial reports: aqueous humour positive, CSF negative.

tIn addition, Case 8 ( $M r$ BC): subsequent test showed treponeme-like forms that stained by the FA method. 
evidence of active inflammatory disease of the eye. Treponeme-like forms were found in only one case, that of a 51-year-old woman (Case 10), who presented because of closed-angle glaucoma and was found to have untreated congenital syphilis with corneal scarring due to previous interstitial keratitis. She had been treated with topical corticosteroid.

In six cases there was active neurological disease, as indicated by a raised cell count in CSF; treponeme-like forms were found in CSF in three of them and subsequently in a fourth (Mr. IT). The CSF cell count was normal in 33 cases, but treponeme-like forms were found in six.

\section{Previous treatment with corticosteroids}

Of the 21 patients who attended Moorfields, thirteen had received corticosteroids topically, systemically, or both; treponeme-like forms were found in material from ten of them. None of the patients attending the Whitechapel Clinic had been treated with corticosteroids.

\section{Untreated patients}

A total of 21 patients had not received previous treatment for treponemal infection; treponeme-like forms were found in ten of them and a 'doubtful' form in one other (Table IV). Nine of the 21 patients attending the Whitechapel Clinic were untreated; treponeme-like forms were found in CSF from four. Twelve of the 21 patients attending Moorfields were untreated; treponeme-like forms were found in material from six with a 'doubtful' form in material from one other.

TABLE IV Results of initial tests for treponemes in treated and untreated patients

\begin{tabular}{lllll}
\hline Treponeme-like forms & & Found & Not found & Total \\
\cline { 3 - 4 } \cline { 5 - 6 } & & 10 & $11^{\star}$ & 21 \\
Untreated & 7 & $14^{\star}$ & 21 \\
\hline
\end{tabular}

^Includes one 'doubtful'.

\section{SELECTED CASE REPORTS}

\section{(a) Patients attending the Whitechapel Clinic}

Case 28, a British woman aged 56 suffering from tabes dorsalis

BLOOD CWR positive, VDRL weakly positive, RPCFT negative, FTA-ABS 'doubtful' once, positive once, TPI negative.

CSF Normal in all respects except for treponeme-like forms found by means of FA staining and darkfield microscopy.
Case 30, a British homosexual man aged 30 with latent syphilis

BLOOD CWR, RPCFT, FTA-ABS positive, VDRL positive (1 in 4).

CSF Normal except for a positive TPI and treponemelike forms found by means of FA staining and darkfield microscopy.

Case 33, a Pakistani man aged 22 suffering from neurosyphilis. The right pupil was larger than the left, the near reflex and the reaction to light were sluggish.

BLOOD CWR, RPCFT, FTA-ABS and TPI positive, VDRL positive ( 1 in 64$)$.

CSF $30 \mathrm{WBC} / \mathrm{c} . \mathrm{mm}$., protein $60 \mathrm{mg} . / 100 \mathrm{ml}$., Pandy trace, Lange 55543210, CWR, RPCFT, FTA-ABS positive, VDRL positive ( 1 in 4$)$. Treponeme-like forms found by means of FA staining and darkfield microscopy.

The patient was treated with procaine penicillin with 2 per cent. aluminium monostearate, 600,000 units by intramuscular injection, daily for 17 days (total $10 \cdot 2$ mega units). 7 months after treatment the condition of the right pupil was unchanged. However, the reaction to light of the left pupil, that had previously been normal, was diminished, the near reflex remained brisk. Treponeme-like forms were again found in CSF by means of darkfield microscopy, the cell count had fallen to $8 / \mathrm{c} . \mathrm{mm}$., and the protein to $30 \mathrm{mg} . / 100 \mathrm{ml}$., CWR and FTA-ABS positive, VDRL weakly positive, Lange curve normal.

BLOOD CWR and RPCFT positive, VDRL positive ( 1 in 8$)$.

Case 34, a British woman aged 35 with latent syphilis.

BLOoD CWR, RPCFT, and FTA-ABS positive, VDRL positive ( 1 in 64 ).

CSF Normal in all respects except for treponemelike forms found by darkfield microscopy.

\section{(b) Patients attending Moorfields Eye Hospital}

Case 4, Mr IT, a Jamaican aged 27 suffering from persistent uveitis.

BLOOD CWR, VDRL, RPCFT, TPI negative, FTAABS positive. A treponeme-like form was found in aqueous humour by means of FA staining.

CSF $10 \mathrm{WBC} / \mathrm{c} . \mathrm{mm}$., protein $40 \mathrm{mg} . / 100 \mathrm{ml}$., Pandy trace, Lange 111000000, all other results normal. After fully-recorded 'adequate' treatment, a treponeme-like form was found in the CSF by means of FA staining after this study had been completed.

Case 5, Mrs FC, a Jamaican aged 39 with cardiomegaly and long-standing uveitis.

BLOOD CWR and VDRL negative, RPCFT weakly positive, FTA-ABS and TPI positive. A treponeme-like form was found in aqueous humour by means of FA staining.

CSF FTA-ABS positive, Pandy a 'trace'. An unstained treponeme-like form was seen, but findings were otherwise normal. 
Both these patients had been treated with local corticosteroid. There was no clinical evidence of yaws but, as they came from an area in which that disease has been endemic, it is possible that the organisms found were treponemes of yaws. Treponeme-like forms that stained with FA stain and others that did not were present in Case 5 as in some others.

Case 19, a British man aged 56 suffering from progressive loss of vision due to disseminated choroidoretinitis, showed no other sign suggestive of syphilis. He had a past history of gonorrhoea as a young man.

BLOOD All serological tests were repeatedly negative.

CSF Normal except for one treponeme-like form found by means of FA staining; a 'doubtful' form was found in aqueous humour by means of FA staining. This patient had received systemic treatment with corticosteroids.

Case 10, a British woman aged 51, presented because of closed-angle glaucoma. She was suffering from congenital syphilis, with classical scarring from previous interstitial keratitis, and from deafness and vertigo. She had received local treatment with corticosteroid.

BLOOD CWR, FTA-ABS, TPI positive, VDRL positive with neat serum, RPCFT negative.

cSF Normal.

Treponeme-like forms were found in aqueous humour by means of FA staining.

\section{Treated patients}

21 patients had been treated previously for treponemal infection. Treponeme-like forms were found in material from seven and a 'doubtful' form in one other (Table IV). Twelve of the 21 Whitechapel Clinic patients had been treated previously; treponeme-like forms were found in material from two. Nine Moorfields patients had been treated; treponeme-like forms were found in material from five and a 'doubtful' form in one other. Full details of previous treatment were obtained if this was possible.

\section{SELECTED CASE REPORTS}

(a) Patients attending the Whitechapel Clinic The presence of treponeme-like forms after treatment is shown by the findings in Case 33 above.

Case 23, a Caribbean man aged 42, had been treated for yaws in childhood with an unknown number of intramuscular injections

BLOOD CWR, VDRL, and RPCFT negative, FTAABS and TPI positive.

CSF 12,800 red blood corpuscles (RBC)/c.mm., 12 WBC/c.mm., protein $200 \mathrm{mg} .100 \mathrm{ml}$., Pandy positive, Lange 012332, VDRL, RPCFT, CWR, FTA-ABS, and
TPI all negative. Treponeme-like forms were seen on darkfield microscopy but not after FA staining.

The finding in this case, and possibly even in Cases 4 and 5, raised the question whether $T$. pertenue may still be found in adult life following yaws in childhood.

Case 40, a British woman aged 48 suffering from tabes dorsalis and optic atrophy due to congenital syphilis

BLOOD CWR negative on five occasions, VDRL and RPCFT positive on one of five occasions, FTA-ABS and TPI positive.

CSF Normal except for the presence of a treponemelike form on darkfield examination; a 'doubtful' form with only two spirals was also seen by means of FA staining.

She had been treated at the age of 15 with malaria and at the age of 27 with procaine penicillin 900,000 units by intramuscular injection daily for 10 days (total nine mega units).

That treponeme-like forms can be found after the treatment of early syphilis, even in the presence of negative tests for anti-treponemal antibodies, is shown by the case of an additional patient (Case 44) tested after this present series had been completed.

A 43-year-old Indian man was treated for darkfieldpositive sero-negative primary syphilis with 2.4 mega units benzathine penicillin by intramuscular injectior. 7 months later he was treated for darkfield-positive sero-positive primary syphilis with procaine penicillin with 2 per cent. aluminium monostearate, 600,000 units by intramuscular injection, daily for 10 days (total six mega units). 15 months after the second treatment serological tests (including TPI and FTA-ABS) gave negative results. At this time tests of CSF (including FTA-ABS) gave negative results apart from the finding of treponemelike forms on darkfield and immunofluorescence microscopy.

\section{(b) Patients attending Moorfields Eye Hospital}

Case 1, Mr QD, a British youth aged 19, suffering from congenital syphilis with avascular keratitis and Hutchinsonian teeth. He had received two courses of penicillin (total 28 mega units) when congenital syphilis had been diagnosed when he was 6 years old. Each course consisted of 250,000 units by intramuscular injection given four times a day for 14 days. He had also received four courses of bismuth injections. At the age of 17 he had developed keratitis and at 19 treponeme-like forms (Figure, overleaf) were seen in a specimen of aqueous humour stained by the FA method.

BLOOD WR and Kahn negative (tested elsewhere). CWR, FTA-ABS and TPI positive, VDRL weak positive with neat serum.

CSF Normal (Rice and others, 1968; Dunlop and others, 1968). 


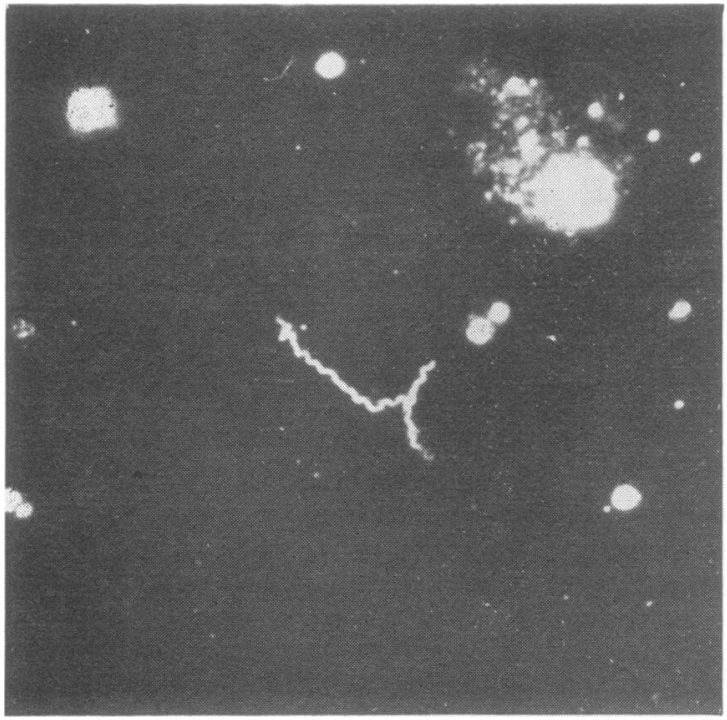

FIGURE Treponeme-like forms in aqueous humour from Mr QD (Case 1). $\times 630$, enlarged $\times 7$.

Case 16, a Jamaican man aged 40 suffering from anterior uveitis and keratitis. Results of serological tests for syphilis were uniformly positive (VDRL positive 1 in 8). At the age of 32 he had been treated for latent syphilis with 2.4 mega units of benzathine penicillin by intramuscular injection and with two injections of bismuth. Despite this, active kerato-uveitis was present at the age of $\mathbf{4 0}$ and treponeme-like forms were found in aqueous humour stained by the FA method.

Case 15, a British man aged 63 suffering from recurrent iritis. Serological tests for syphilis gave uniformly positive results (VDRL positive, 1 in 2 ). At the age of 53 he had been treated for iritis and asymptomatic neurosyphilis with 900,000 units of procaine penicillin by intramuscular injection daily for 15 days (total 13.5 mega units) and with bismuth $0.3 \mathrm{~g}$. weekly by intramuscular injection for 10 weeks. At the age of 60 he had received 1,250,000 units of penicillin as 'Triplopen' by intramuscular injection three times a week for 3 weeks (total 11.25 mega units). Initially tests of CSF were reported as follows: $15 \mathrm{WBC} / \mathrm{c} . \mathrm{mm}$., increased globulin, total protein $15 \mathrm{mg} . / 100 \mathrm{ml}$., Lange 0123322210 , WR negative. At the age of 63, treponeme-like forms were found in aqueous humour by means of FA staining but none was found in CSF which contained $45 \mathrm{mg}$. protein per $100 \mathrm{ml}$. The TPI was positive; all other tests of CSF gave normal results.

These three patients had all received local corticosteroids.

\section{Serological tests for syphilis}

Results will be presented in detail when sufficient material is available for analysis under each diagnosis. In the cases of patients presenting because of disease of the eye, tests for 'reagin' and for anti-treponemal antibodies gave negative results in two cases in which treponemes were found:

Case 3, Mr KT, a British man aged 49, gave a history, which could not be substantiated, of 'primary syphilis' treated at the age of 23 with arsenic and bismuth. Retinal changes suggestive of retinitis pigmentosa were observed when he was 43 years old and anterior uveitis developed at age 46 ; at age 49 the results of the TPI and FTA-ABS tests were reported as negative, on two further occasions the results of the TPI were reported as 'doubtful', and those of the FTA-ABS were 'doubtful' on one occasion and negative on another; otherwise all serological tests gave negative results. Microscopy after FA staining showed treponeme-like forms in aqueous humour and a weakly staining treponeme-like form in CSF. Results of other tests of CSF were as follows: $6 \mathrm{WBC} / \mathrm{c} . \mathrm{mm}$., protein $40 \mathrm{mg} . / 100 \mathrm{ml}$., Pandy test positive, Lange curve 22211000, CWR, VDRL, RPCFT, FTA-ABS, and TPI all negative (Dunlop and others, 1968; Rice and others, 1968).

Case 19, a British man aged 56 with increasing loss of vision due to choroido-retinitis. There was no other clinical or historical evidence of syphilis, but he gave a history of having had gonorrhoea when a young man. All serological tests repeatedly gave negative results. Microscopy after FA staining showed a treponeme-like form in CSF, but all other tests of CSF gave normal results. A 'doubtful' non-staining form was found in aqueous humour.

In Case 4 as noted above (the 27 -year-old Caribbean (Mr IT) suffering from active iritis), the FTA-ABS was the only serological test that gave a positive result (Dunlop and others, 1968). A treponeme-like form was found in aqueous humour by means of FA staining. Subsequent tests showed similar forms in CSF.

Only the VDRL gave positive results in the following case:

Case 2, Mrs MU, a 68-year-old British woman $\frac{0}{\mathscr{D}}$ suffering from congenital syphilis (Dunlop and $\cong$ others, 1968), had received only eight intravenous injections at the age of 20 years. At the age of 68 she was found to have scarring from previous interstitial keratitis, choroido-retinal scarring, and active anterior uveitis. Treponeme-like forms were found in aqueous humour by microscopy after FA staining, but all serological tests gave negative results, except the VDRL which was positive with neat serum. The persistence of 'reagin' in the absence of anti-treponemal antibody in the case 
of this patient with undoubted long-standing syphilis could be described as a 'pseudo biological false-positive reaction'.

All these patients who had presented because of inflammatory disease of the eye had received corticosteroids locally, systemically or by both routes; but none had been given in the case of the 43-year-old Indian man (Case 44) referred to above, in which 15 months after 'adequate' fully-recorded treatment of sero-positive primary syphilis, treponeme-like forms were found in otherwise normal CSF, although by then serological tests for syphilis all gave negative results.

\section{Discussion}

Treponemes are identified in fixed preparations by their morphological appearances as seen by microscopy using darkfield illumination or after staining with silver or with 'specific' immunofluorescence stains. They are also identified by their characteristic motility in wet darkfield preparations and by the experimental infection of animals.

Identification on morphological grounds alone may be fallacious. Wilkinson (1968) and Montenegro and others (1969) have reported that artefacts and filaments may closely resemble treponemes, so that it is conceivable that they may even be indistinguishable from treponemes.

In this study, organisms were identified on the grounds of morphological appearance and ability to combine, in an immunofluorescence test, with syphilitic serum from which group antitreponemal antibody had been removed by absorption with the Reiter treponeme. Whether this absorption is adequate to abolish reactivity of such a serum with all treponemes except $T$. pallidum and the closely allied $T$. pertenue, the cause of yaws, is not yet known. Reactivity with $T$. pertenue was shown during this study: material was examined that had been obtained by aspiration of a lymph node of an 8-year-old Caribbean girl (Case 43), suffering from late secondary yaws, who had left St. Vincent 6 months earlier; treponemes were not seen on darkfield microscopy, but after direct FA staining both non-fluorescent and fluorescent treponeme-like forms were seen.

Examination of the wet centrifuged deposit of CSF by darkfield microscopy showed six treponemelike forms in six cases, in three of which the forms exhibited sluggish movement. This motility could be distinguished from the effect of Brownian movement, but was not as active as that of $T$. pallidum when freshly obtained from lesions of infectious syphilis. Examination of aqueous humour by this method was not attempted because of the small amount of material available.
The possibility must be investigated that treponemes other than T. pallidum, pathogenic or nonpathogenic, may become disseminated through the body and persist. The detection of treponeme-like forms in material from patients coming from areas in which yaws was endemic raised the possibility that the treponeme of yaws might persist for long periods in the tissues and might even be a cause of disease attributed to late syphilis.

Tests of the infectivity for animals of the treponemes seen in this study were not undertaken, so that conclusive proof that they were $T$. pallidum is lacking.

This study confirms that treponeme-like forms can be found in some cases of patients with longstanding treponemal infection, both untreated and after what is currently regarded as adequate treatment, and even in sero-negative cases. It has long been suspected that treponemes may be more difficult to eradicate in cases of late than of early syphilis. Nevertheless, Boncinelli and others (1966) reported finding treponemes by silver-staining of material obtained by lymph node puncture in one of eight cases of recently treated early syphilis and in four of eight cases of treated TPI-positive syphilis. The patient with treated early syphilis had received 15 mega units of penicillin in 15 days, finishing only 10 days before the test, so it is possible that the organisms found were dead. In the present study, treponeme-like forms were found in CSF from a patient 15 months after he had received fullyrecorded treatment for primary syphilis that was successful as judged by clinical and serological results. If these and the other treponeme-like forms found in this study were $T$. pallidum, it is possible that their virulence was attenuated, as has been suggested for 'persistent' treponemes found by other workers.

In cases of syphilis, tests for treponemes directly detect the agent of disease, whereas serological tests for treponemal infection detect only responses by the body to infection, and these may be deficient or absent. When the results of serological tests are positive they do not necessarily indicate that the infection is active or that a particular lesion is due to syphilis. The finding of treponemes in material from the affected area, as in the aqueous humour in a case of iritis, would make it likely that the organisms were the cause of the local disease; nevertheless, it would still be possible that the iritis was due to some other coincidental cause and all the findings in each case must be considered together. The detection of treponeme-like forms in aqueous humour from nine of eleven cases of clinically active inflammatory disease of the eye suggests that these agents were the 
cause of the clinical disease. A further correlation with active inflammatory change has been reported by Christman and others (1968): of six cases of active uveitis there was improvement after treatment in five in which treponeme-like forms could no longer be found; relapse then occurred in two in which the forms were again found. In the case that did not improve after treatment treponeme-like forms were seen to persist.

There was some correlation between the presence of treponeme-like forms and a raised cell count in the CSF. Nevertheless, these forms were found in seven cases, including the additional case (44) in which cell counts were normal.

In the past, tests for treponemes have been practicable only in the early stages of infection. However, if the tests used are specific and sensitive enough, it is possible that they may afford valuable information even in the late stages of disease, both in diagnosis in selected cases and in follow-up after treatment.

Manifestations of syphilis depend upon tissueresponse to the presence of treponemes. Corticosteroids alter this response and may increase the number of organisms present. Nevertheless, treponeme-like forms were found in material from patients who had not received corticosteroids as well as from those who had.

This preliminary investigation was mainly intended to assess the value of tests of aqueous humour and of CSF for treponemes, as an aid to diagnosis in the cases of selected patients suffering from ocular disease, and of unselected treated and untreated patients attending a clinic because of treponemal infection. The treponeme-like forms in such cases must be further identified. It is necessary to examine more 'controls' and also a much larger series of patients both before and after treatment and at various stages of disease. Whatever the nature of apparently persisting treponemes, it is only the early lesions of syphilis that are infectious by sexual contact. Until further information is available, and the possible significance of such treponeme-like forms for individual patients can be assessed, it is not advisable to alter methods of treatment of early syphilis, the clinical results of which are excellent.

\section{Summary}

In a collaborative study at Moorfields Eye Hospital and at The London Hospital, darkfield microscopy and fluorescent antibody methods were used to detect treponemes in cerebrospinal fluid (CSF), aqueous humour, and subretinal fluid.

21 patients, diagnosed at the Whitechapel Clinic of The London Hospital as having syphilis (or yaws), were tested; treponeme-like forms were found in CSF from six. An additional case is recorded in which such forms were found in the CSF of a patient in whose case all serological tests (CWR, VDRL, RPCFT, FTA-ABS, TPI) gave negative results; 15 months previously this sero-negative patient had received apparently successful and fully recorded treatment for sero-positive primary syphilis.

21 patients who attended Moorfields Eye Hospital because of ocular disease were studied. In the cases of nineteen of them there was definite evidence of treponemal infection; in the remaining two there was no such definite evidence but choroido-retinal changes were strongly suggestive of syphilis and microscopy showed the presence of treponeme-like forms. Aqueous humour was tested in eighteen cases; treponeme-like forms were found in ten. CSF was tested in eighteen cases; treponeme-like forms were found in three.

In all, 21 patients who had not been treated previously for treponemal disease were tested; treponeme-like forms were found in material from ten.

21 patients who had been treated previously were tested; treponeme-like forms were found in material from seven. The organisms were present in the aqueous humour of a youth aged 19 suffering from interstitial keratitis, who had been treated for congenital syphilis with 28 million units of penicillin and with bismuth at the age of 6 years.

Eleven patients suffering from active inflammation of the eye were tested; treponeme-like forms were found in aqueous humour from nine.

It seems probable that at least some of the forms that were seen were $T$. pallidum. Even if this is so, the findings do not alter the fully-substantiated facts that the clinical results of treatment of early syphilis are excellent and that it is only the moist lesions of early syphilis that are infectious by sexual contact.

Tests that directly demonstrate the agent may of prove to be valuable in diagnosis and follow-up in $N$ the late as well as in the early stages of treponemal $\mathrm{N}$ disease.

Financial support has been received from the Wellcome Trust for continuation and extension of this investigation, and from the World Health Organization for experimental studies in animals.

We are grateful to our colleagues who referred patients for investigation; to Mr Hung Cheng, F.R.C.S., who obtained the two specimens of subretinal fluid for examination; and to Mr C. J. Storey, Mr H. G. Ferguson, A.I.M.L.T., and Mr G. W. Lavender, A.I.M.L.T., for technical assistance. 


\section{References}

Boncinelli, U., Vaccari, R., Pincelli, L., and LancelLOTTI, M. (1966). G. ital. Derm., 107, 1.

Christman, E. H., Hamilton, R. W., Heaton, C. L., and HoffMeyer, I. M. (1968). Arch. Ophthal. (Chicago), 80, 303.

Collart, P., Borel, L-J., and Durel, P. (1962a). Ann. Inst. Pasteur, 102, 596.

$\longrightarrow,-,-$ (1962b). Ibid., 102, 693.

,,$---(1962 c)$. Ibid., 102, 953.

__ —_ - (1964). Brit. F. vener. Dis., 40, 81.

Dunlop, E. M. C., KIng, A. J., and Wilkinson, A. E. (1968). Trans. ophthal. Soc. U.K., 88, 275.

GAGER, W. E., IsRAEL, C. W., and SMITH, J. L. (1968). Brit. F. vener. Dis., 44, 277.

Golden, B., WATZKe, R. C., Lindell, S. S., and MCKeE, A. P. (1968). Arch. Ophthal. (Chicago), 80, 727.

Goldman, J. N., and GIRARD, K. F. (1967). Ibid., 78, 47. - - (1968). Ibid., 79, 716.

Jones, B. R., Patterson, A., and Rice, N. S. C. (1968). Trans. ophthal. Soc. U.K., 88, 235.

Mack, L. W., Smith, J. L., Walter, E. K., Montenegro, E. N. R., and Nicol, W. G. (1969). Arch. Otolaryng., 90, 11.

Montenegro, E. N. R., Israel, C. W., Nicol, W. G., and Smith, J. L. (1969). Amer. F. Ophthal., 67, 335.

-, Nicol, W. G., and SMITH, J. L. (1969). Ibid., 68, 197.

RICE, N. S. C., Jones, B. R., and WILKINSON, A. E. (1968). Trans. ophthal. Soc. U.K., 88, 257.

Smith, J. L., and IsRael, C. W. (1967a). Arch. Ophthal. (Chicago), 77, 474.

$\longrightarrow,-$ (1967b). J. Amer. med. Ass., 199, 980.

— - - (1968). Brit. F. vener. Dis., 44, 109.

- - - and Harner, R. E. (1967). Arch. Ophthal. (Chicago), 78, 284.

- - MCCRARY, J. A., and Harner, R. E. (1968). Amer. F. Ophthal., 65, 242.

WILkINSON, A. E., (1968). Trans. ophthal. Soc. U.K., 88, 251.

Yobs, A. R., Clark, J. W., JR., Mothershed, S. E., Bullard, J. C., and Artley, C. W. (1968). Brit. $\mathcal{F}$. vener. Dis., 44, 116.

—, Rockwell, D. H., and ClaRK, J. W., JR. (1964). Ibid., 40, 248.

Mise en evidence de formes ressemblant au tréponème dans la syphilis tardive traitée et non traitée et dans la syphilis récente traitée

\section{SOMMAIRE}

Lors d'une étude coopérative, au Moorfields Eye Hospital et au London Hospital, des recherches microscopiques au fond noir et des méthodes de mise en évidence de l'anticorps fluorescent furent employées pour rechercher les tréponèmes dans le liquide céphalorachidien (LCR), l'humeur aqueuse et le liquide sous-rétinien.

Vingt et un malades de la Whitechapel Clinic, au London Hospital, reconnus comme atteints de syphilis (ou de pian) furent étudiés; des formes ressemblant au tréponème furent trouvées dans le LCR de six d'entre eux. On rapporte un cas supplémentaire d'un malade chez lequel ces formes furent trouvées dans le LCR alors que les tests sérologiques (Wassermann, VDRL, RPCF, FTA-ABS, TPI) s'étaient montrés négatifs; quinze mois auparavant, ce malade avait reçu un traitement important et apparemment suivi de succès, pour une syphilis primaire séro-positive.

Vingt et un malades, consultant au Moorfields Eye Hospital pour des troubles oculaires, furent étudiés. Pour dix-neuf d'entre eux une infection tréponémique était évidente; pour les deux autres cette évidence n'était pas si flagrante mais les altérations choriodo-rétiniennes évoquaient fortement la syphilis et l'étude microscopique montra des formes ressemblant au tréponème. L'humeur aqueuse fut étudiée dans dix-huit cas; des formes ressemblant au tréponème furent trouvées dans dix cas. Le LCR fut examiné dans dix-huit cas; des formes ressemblant au tréponème furent trouvées dans trois d'entre eux.

En tout, vingt et un malades, qui n'avaient pas été traités antérieurement pour une infection tréponémique, furent examinés: des formes ressemblant au tréponème furent trouvées chez dix d'entre eux.

Vingt et un malades furent étudiés, qui avaient été traités antérieurement; des formes ressemblant au tréponème furent trouvées chez sept d'entre eux. Ces formes furent observées dans l'humeur aqueuse d'un jeune de dix-neuf ans atteint de kératite interstitielle; ce malade avait été traité à l'âge de six ans pour syphilis congénitale par 28 millions d'unités de pénicilline associée au bismuth.

Onze malades atteints d'inflammation évolutive de l'oeil furent examinés; des formes ressemblant au tréponème furent trouvées dans l'humeur aqueuse chez neuf d'entre eux.

Il apparaît probable qu'au moins certaines des formes observées étaient des $T$. pallidum. Même s'il en est bien ainsi, ces constatations ne modifient pas les faits largement établis que les résultats du traitement de la syphilis récente sont excellents et que c'est seulement les lésions humides de syphilis récente qui sont contagieuses par contact sexuel. Les recherches qui mettent directement en évidence le tréponème peuvent avoir une valeur dans le diagnostic et dans la surveillance de la maladie tréponémique, tardive aussi bien que recente. 